\title{
Peran Kiai Sebagai Inisiator dan Elitist Charismatic dalam Membentuk Akuntabilitas Nahdlatul Ulama
}

\author{
Novi Wulandari \\ Universitas Brawijaya Malang \\ Jalan Veteran no. 2, Kota Malang, Indonesia, 65146 \\ noviwulandari77@gmail.com
}

\begin{abstract}
Nahdlatul Ulama (NU) is a religious organization that has a representative from traditional ulama with the ideology of ahlus sunnah waljamaah. Along with its development, NU still holds a culture that is derived from its predecessors (Kiai) in managing the organization, both in the organizational structure and in terms of organizing community-based non-profit organizations that have a principle of accountability. For this reason, the purpose of this research is to analyze and describe the reality of the role of the Kiai in forming NU's accountability. The research perspective used is the interpretive paradigm with qualitative research methods through a multiple case study approach. The results of the study revealed that the role of the Kiai as an initiator in establishing accountability was shown by the provision of ideas in accordance to the needs of $N U$ residents in particular, and the Indonesian State in general. This role can be categorized as the Elitist-charismatic values - which is the value system of pride of the charismatic leader which results in the fanaticism of the members of the organization. Since the charismatic nature of the kiai is temporary, these values are transitional. NU's accountability process is called "Typical Accountability of Lillahita'ala and Ikhlas in the style of NU". The purpose of the accountability of Lillahita'ala and Ikhlas is the principle of honesty and sincerity in preparing financial statements.
\end{abstract}

Keywords: Accountability, Initiator, Elitist Charismatic Kiai, Nahdlatul Ulama (NU)

\begin{abstract}
Abstrak
NU merupakan organisasi agama yang yang memiliki reprensentatif dari ulama tradisional dengan ideologi ahlus sunnah waljamaah. Seiring perkembangannya, ternyata NU masih memegang budaya yang diturunkan dari para pendahulunya (Kiai) dalam mengelola organisasinya, baik dalam struktur organisasi maupun dalam hal penyelenggaraan organisasi nirlaba berbasis masyarakat yang berprinsip akuntabilitas. Melihat hal tersebut, maka tujuan dalam penelitian ini adalah menganalisis dan mendeskripsikan secara mendalam tentang realitas peran Kiai dalam membentuk Akuntabilitas NU. Prespektif penelitian yang dipakai adalah paradigma interpretif dengan metode penelitian kualitatif melalui pendekatan studi kasus kolektif (collective or multiple case study). Hasil penelitian diketahui bahwa Peran Kiai sebagai inisiator dalam membentuk Akuntabilitas ditunjukkan adanya pemberian gagasan sesuai dengan kebutuhan warga NU pada khususnya dan Negara Indonesia pada umumnya. Peran Kiai yang sedemikian besar tersebut dikategorikan dalam nilai tipe elitist charismatic values, yang merupakan sistem nilai kebanggaan diri dari pimpinan yang kharismatik yang menghasilkan fanatisme para anggota organisasi. Mengingat sifat kharismatik dari kiai bersifat temporer, maka nilai-nilai ini bersifat transisional. Proses akuntabilitas NU ini disebut "Akuntabilitas Khas Lillahita'ala dan Ikhlas ala NU”. Maksud dari akuntabilitas Lillahita'ala dan Ikhlas ini adalah adanya prinsip kejujuran dan keikhlasan dalam menyusun laporan keuangan.
\end{abstract}

Kata Kunci:Akuntabilitas, Inisiator, Elitist Charismatic Kiai, NU

\section{PENDAHULUAN}

Praktik akuntabilitas sangat diperlukan dalam setiap organisasi. Akuntabilitas merupakan salah satu prinsip dari pelaksanaan Good Corporate Gorvernance (GCG) yang meliputi fairness, transparency, accountability and responsibility. Desakan mengenai pelaksanaan Good Corporate Governance tidak terbatas hanya pada organisasi privat, tetapi juga pada organisasi publik termasuk organisasi keagamaan (Randa, Triyuwono, Ludigdo, \& Sukoharsono, 2011).

NU merupakan non-governmental organization (NGO) yang pengelolaannya berbasis masyarakat berdasarkan prinsip mutual cooperation yaitu prinsip gotong royong antar sesama anggota maupun non-anggota (pihak diluar anggota arganisasi seperti donatur). Antara sesama anggota maupun non-anggota memiliki visi dan misi yang sama yaitu memiliki kepedulian yang 
sama dengan fokus untuk meningkatkan kinerja (Ebrahim, 2003; Kaplan, 2001). Konsekuensinya, seluruh keputusan dan tindakan organisasi harus akuntabel atau dapat dipertanggungjawabkan pada seluruh anggota organisasi dan stakeholders yang berkepentingan agar tercipta check and balance yang akan mendukung keberlanjutan organisasi (UNDP 1997).

Akuntabilitas keuangan dalam sebuah organisasi keagamaan sangat penting untuk dilakukan. Akuntabilitas keuangan dalam organisasi keagamaan dapat diartikan sebagai kewajiban pemegang amanah untuk memberikan pertanggungjawabannya kepada pihak pemberi amanah (umat/donator) yang memiliki hak untuk meminta pertanggungjawaban atas penggunaan dana tersebut. Namun yang menarik, meski proses akuntabilitas di organisasi nirlaba terus dikritik dan diragukan kehandalannya (Cutt \& Murray, 2010; Ebrahim, 2003; Kaplan, 2001), banyak organisasi nirlaba yang dapat terus beraktivitas dan bertahan dalam waktu panjang (Prugsamatz, 2010).

Beberapa ahli yang meneliti kondisi paradoks tersebut menemukan fakta, bahwa terdapat model akuntabilitas yang beyond (melampaui) model akuntabilitas mainstream, seperti laporan keuangan dan laporan tahunan yang umumnya digunakan, yang terbentuk dari budaya dan nilai yang dianut organisasi (Awio, Northcott, \& Lawrence, 2011; Berry, 2005; Jacobs, 2005; Jayasinghe \& Soobaroyen, 2009). Meskipun penerapan akuntabilitas organisasi khususnya dalam hal ketersediaan laporan pertanggungjawaban dan laporan keuangan masih kurang efektif, legitimasi organisasi dihadapan seluruh stakeholder tetap terjaga dan organisasi tetap dapat beraktivitas seperti biasa (Awio et al., 2011; Berry, 2005; Jacobs, 2005; Jayasinghe \& Soobaroyen, 2009)

Sementara itu, dari penelitian yang telah dilakukan oleh Mandasari, Darmawan, \& Atmadja (2015), dapat dijelaskan bahwa dalam mengelola keuangan dana bantuan sosial (bansos) yang diterima ternyata sudah sesuai dengan proposal yang diajukan. Pengelolaan keuangan dilakukan secara hati-hati, terbuka, jujur dan amanah dengan pemahaman spiritual yang tinggi sebagai dasar pemahaman akuntabilitas pengelolaan keuangan dana bansos. Konsep akuntabilitas pengelolaan keuangan pada Majelis Ta'lim Muslimat NU Ukhuwah Islamiyah Kampung Anyar Singaraja Bali mencakup unsur transparansi, liabilitas, kontrol, responsibilitas, dan responsivitas. Selanjutnya berdasarkan penelitian yang dilakukan Mardiyah (2012), bangunan budaya pesantren pada Pondok Modern Gontor, Pondok Pesantren Lirboyo dan Pesantren Tebuireng dapat merepresentasikan adanya kepemimpinan Kiai yang efektif. Kepemimpinan tersebut berdasarkan peran Kiai dalam menjaga budaya pesantren diantaranya melalui proses seleksi yang berbeda, adanya proses sosialisasi, dan adanya tindakan manajemen puncak.

Berbagai kajian yang dilakukan oleh beberapa peneliti mengindikasikan bahwa NGO khususnya NU menarik untuk dijadikan obyek penelitian khususnya terkait akuntabilitas NU, mengingat beberapa hal antara lain. Pertama, NU yang pada awal berdiri merupakan organisasi keagamaan yang menjadikan seorang kiai sebagai figur penyanggah utama yang berbasis pada pesantren (kiai-santri). Sepanjang sejarahnya NU mengalami proses transformasi yang mewarnai dinamika perjalanannya, di mana NU sejak awal berdirinya diklaim sebagai kelompok tradisionalis kini merambah dalam kancah kehidupan yang lebih terbuka di samping lahirnya sarjana-sarjana NU yang telah bersentuhan wacana modernitas dan komunitas akademis. Hal itu merupakan fenomena baru dalam organisasi keagamaan ini.

Kedua, NU yang menjadikan kiai sebagai figur sentral juga telah mengalami banyak perubahan atau pergeseran, di samping karena kiai itu sendiri mulai terbuka terhadap nilai-nilai baru. Bahkan telah bersentuhan secara intensif dengan politik termasuk politik praktis, fenomena ini misalnya tampak ketika NU menjadi partai politik tahun 1950-an dan belakangan dalam era reformasi, pimpinan tertinggi NU seperti KH. Abdurrahman Wahid terpilih menjadi presiden RI ke-empat, KH. Kholil Bisri menjadi Wakil ketua MPR dan beberapa kiai yang aktif dalam PKB dan partai berbasis NU lainnya menggiring beberapa kiai menjadi anggota legislatif. Meskipun demikian, sebagian besar ulama NU tetap memilih berkiprah secara penuh dengan membina pondok pesantren masing-masing.

Ketiga, langkah-langkah progresif dan aksi atau gerakan kaum muda NU yang eksis di jalur kultural menjadi fenomena menarik, khususnya dalam membangun proyek pemberdayaan civil society. Kiprah kaum muda NU di jalur kultural ini menjadi bagian proses transformasi yang menunjukkan bahwa NU kini dan ke depan semakin eksis dengan mengadopsi perkembangan yang terjadi dalam berbagai aspeknya (Muhammad, 2017). Kiai sebagai tokoh dalam masyarakat tradisional dan merupakan pemimpin non-formal sering melakukan perubahan besar di dalam masyarakatnya. Dikatakan perubahan besar karena struktur masyarakat yang 
diubah memang selalu sejalan dengan apa yang Kyai kehendaki karena azas kepatuhan masyarakat kepada Kyai.

Berdasarkan fenomena tersebut dapat diidentifikasi bahwa pergeseran paradigma NU tidak terlepas dari sosiokultural dan kondisi yang menyertai proses terbentuknya akuntabilitas dalam tubuh NU. Sikap keterbukaan kaum NU terhadap nilai-nilai modernitas serta munculnya sarjana-sarjana NU juga berpengaruh terhadap dinamika perkembangan NU. Namun demikian, keberadaan kiai-kiai NU di pesantren tetap sebagai penyanggah utama yang merupakan basis NU yang tetap dipertahankan dan diberdayakan. Proses yang terjadi tersebut berlangsung melalui komitmen untuk pengembangan dan pemberdayaan umat setelah melalui proses yang cukup panjang dimana ke depan akan melahirkan generasi dari kiai intelektual. Dalam konteks ini, NU relevan untuk dianalisis berdasarkan kekayaan khasanah dan nilai-nilai tradisi yang dianutnya, sehingga dalam perjalanannya selalu dinamis.

Kemudian dalam perkembangannya, transformasi dalam tubuh NU dalam membentuk akuntabilitas organisasi, ternyata masih terjadi beberapa kelemahan di dalamnya. Ada dua indikator utama yang menunjukkan bahwa penerapan praktik akuntabilitas masih sangat lemah di tubuh NU. Pertama, manajemen organisasi NU lebih mengedepankan gaya dan tradisi manajemen pesantren. Manajemen pesantren ini sepenuhnya menempatkan Kiai sebagai pengambil keputusan utama. Hal ini dikarenakan, secara historis NU itu juga adalah pesantren (Baso, 2015a, 2015b). Kedua, NU belum memperhatikan pentingnya sistem pengelolaan dan pertanggungjawaban keuangan. Selama ini, NU hanya mengelola keuangannya berbasis laporan penerimaan dan pengeluaran kas semata.

Berdasarkan pemaparan paradoksnya kondisi akuntabilitas di tubuh NU tersebut, menjadi menarik untuk mengkaji akuntabilitas NU lebih dalam lagi. Khususnya, dalam rangka mencari kemungkinan (telah) hadirnya model akuntabilitas di tubuh NU yang melampaui (beyond) model akuntabilitas mainstream. Berdasarkan fakta, meski NU belum sepenuhnya menerapkan model akuntabilitas mainstream, legitimasi NU di kalangan anggotanya tetap terjaga hingga menjelma menjadi organisasi kemasyarakatan terbesar di Indonesia (Baso, 2015a, 2015b).

Melihat realita yang terjadi tersebut, transformasi dan akuntabilitas pada NU, pendekatan teori yang di pakai dalam penelitian ini adalah dengan menggunakan konsep teori budaya organisasi dengan tipe nilai organisasi. Budaya organisasi menurut (Sutrisno, 2010) diartikan sebagai perangkat sistem nilai-nilai (values), keyakinan-keyakinan (beliefs), asumsi-asumsi (assumptions), atau norma-norma yang telah berlaku, disepakati dan diikuti oleh para anggota suatu organisasi sebagai pedoman perilaku dan pemecahan masalah-masalah organisasinya. Karena nilai ini merupakan hasil dari sebuah budaya, maka pendekatan nilai yang dipakai adalah dengan menggunakan tipe nilai-nilai dalam organisasi milik (Wiener, 1988). Wiener menggunakan tipe nilai dalam organisasi berdasarkan perspektif anggota organisasi sebagai dasar pijakannya yakni sejauh mana espoused values dianggap sentral dan sejauh mana nilai-nilai tersebut disebar oleh para anggota organisasi. Lebih lanjut, Wiener membagi tipe nilai ini menjadi dua dimensi yaitu apakah nilai-nilai tersebut bersifat fungsional atau elitist. Functional values merupakan nilai-nilai organisasi yang merupakan pedoman bagi anggota organisasi dalam melakukan kegiatan dalam organisasi. Sedangkan Elitist Values adalah nilai-nilai organisasi yang menekankan pada arti penting sebuah organisasi atau kebanggan terhadap organisasi.

Dengan menggunakan pendekatan budaya organisasi dengan tipe nilai tersebut, dapat diketahui peran Kiai sebagai inisiator dalam memberikan gagasan sesuai dengan kebutuhan warga NU serta peran kiai sebagai Agent of Culture Change dalam mempersatukan elemen-elemen yang ada dalam organisasi, serta dapat menginisiasi engagement, untuk membangun momentum bersama dalam membentuk akuntabilitas NU. Hal ini dikarenakan dalam budaya organisasi tidak bisa terlepas dari peran pemimpinya, tidak terkecuali peran Kiai dalam membentuk akuntabilitas NU. Untuk itu, penelitian ini berusaha melakukan kajian secara mendalam guna melihat peran Kiai dalam membentuk akuntabilitas NU dengan tujuan untuk menganalisis serta memahami secara mendalam tentang realitas peran Kiai dalam membentuk Akuntabilitas NU.

\section{METODE}

Penelitian ini merupakan penelitian kualitatif dengan pendekatan studi kasus, yaitu pendekatan penelitian kualitatif yang digunakan untuk memahami suatu isu atau permasalahan dengan menggunakan suatu kasus (Creswell, 2013). Dalam penelitian ini, jenis studi kasus yang digunakan peneliti adalah dengan menggunakan studi kasus kolektif (collective or multiple case study). Penelitian ini hanya terfokus pada satu isu atau perhatian akan tetapi memenfaatkan banyak kasus lain untuk menjelaskannya. Hal ini dikarenakan penelitian tidak hanya dilakukan di 
kantor Pengurus Besar Nahdlatul Ulama (PBNU) pusat saja, tetapi juga di kantor pengurus wilayah, pengurus cabang, pengurus muslimat, dan pondok pesantren.

Kemudian analisis data yang dipakai dalam penelitian ini adalah interactive model of analysis. Analisis data kualitatif menurut Bogdan dan Biklen dalam Moleong (2012) adalah upaya yang dilakukan dengan jalan bekerja dengan data, memilah-milahnya menjadi satuan yang dapat dikelola, menemukan apa yang penting dan apa yang dipelajari, serta memutuskan apa yang dapat diceritakan kepada orang lain. Kemudian analisis model interaktif itu sendiri terdiri atas 3 (tiga) komponen, yaitu: (1) Pemadatan Data (Data Condensity), dimana data yang dikumpulkan dari proses observasi di lapangan dituangkan dalam uraian laporan yang lengkap dan terinci. Pemadatan data dilakukan terus menerus selama proses penelitian berlangsung; (2) Penyajian Data (Data Display), hal ini dimaksudkan agar lebih mempermudah bagi peneliti untuk dapat melihat gambar secara keseluruhan bagian-bagian tertentu dari data penelitian; (3) Penarikan Kesimpulan (Concluding Drawing), dalam hal ini verivikasi data dilakukan secara terus-menerus sepanjang proses penelitian dilakukan (Miles, Huberman, \& Saldaña, 2014). Tahapan untuk menarik kesimpulan dari kategori-kategori data yang telah direduksi dan disajikan untuk selanjutnya menuju kesimpulan akhir yang mampu menjawab permasalahan yang dihadapi.

Pengumpulan data dilakukan dengan cara observasi, wawancara mendalam dan dokumentasi. Observasi dilakukan untuk memperoleh gambaran dari fenomena mendalam peran Kiai dalam menbentuk akuntabilitas NU. Wawancara mendalam dilakukan dengan cara mengajukan pertanyaan kunci kepada informan dengan tujuan untuk menggali life history responden dan datadata yang mungkin belum tergali pada saat wawancara biasa. Kemudian teknik terakhir yang dipakai adalah dokumentasi, metode ini dilakukan dengan melalui pencatatan atau penyalinan data yang ada dalam lokasi penelitian. Biasanya data ini berupa data sekunder atau data yang telah ada, misalnya arsip-arsip, foto-foto, laporan tahunan, hasil rapat atau dokumen lainnya di lapangan yang berkaitan dengan penelitian ini.

\section{HASIL DAN PEMBAHASAN}

\section{Akuntabilitas Khas Lillahita'ala dan Ikhlas ala Nahdlatul Ulama}

NU sebagai organisasi yang besar, memiliki budaya yang sangat kuat yang diturunkan dari para pendahulunya. Dari sejarah berdirinya NU dan penelitian di lapangan, maka peneliti menemukan bahwa NU harus dipahami dari sisi NU itu sendiri. NU harus dipahami dari konteks budaya Nusantara yang sangat kental dengan tradisi dan norma-norma yang ditemui di pesantren.

Secara umum, dalam proses akuntabilitasnya mulai dari tingkat pusat sampai dengan ranting memang belum ditemukannya pencatatan yang rapi, terstruktur, dan dipublikasikan secara berkelanjutan kepada publik sebagai bentuk tanggung jawab organisasi terhadap publik. Hal ini tentu menjelaskan bahwa capaian yang ada selama ini terjadi secara sporadis dan sangat tergantung pada kemampuan sekelompok pengurus, dan bukannya sebagai perwujudan visi dan misi NU atau merupakan prestasi yang dapat diakui bahwa itu adalah keberhasilan NU secara umum. Namun disisi lain, administrasi yang baik tidak selalu menghasilkan ketertarikan dari jamaah juga menjadi baik. Hal tersebut seperti yang diungkapkan Gus Mujib Syadzili:

... administrasi yang baik tidak selalu menghasilkan ketertarikan dari jamaah juga menjadi baik. Hal itu dibuktikan dari segi keanggotaan yang sampai dengan tingkat di bawah masih terpelihara di NU, meskipun dikelola secara tradisional. Untuk itu, jika Nahdlatul Ulama (NU) itu ditata secara modern, justru akan berdampak pada berkurangnya jamaah yang menjadi semakin kecil.

Pada dasarnya memang akuntabilitas merupakan konsep modern yang mengedepankan nilai-nilai budaya transparansi dalam berorganisasi. Namun pada kenyataannya NU sudah memiliki corak yang berbeda dengan teori-teori akuntabilitas modern. Kaum Nahdliyin mempercayai para Kiai sebagaimana pendahulu mereka sebelum berbentuk NU seperti sekarang sudah memiliki pengaruh terhadap santrinya. Hal ini dikarenankan kebanyakan yang menjadi pengurus NU adalah seorang santri yang taat betul terhadap Kiai, sebagaimana Ungkapan Gus Mus :

Kiai disini tentu punya pikiran dan kelakuan yang sama dengan Kiai lainnya untuk sedapat mungkin meniru jejaknya Nabi Muhammad SAW. Hal ini lah yang membuat para santri yang duduk sebagai pengurus organisasi NU yakin bahwa Kiai itu penerus Nabi yang harus dipatuhi dan diteladani.

Pendapat yang disampaikan oleh Gus Mus itulah yang kemudian menjadi titik pokok kepercayaan warga NU kepada NU itu sendiri. Pendirian bahwa para Kiai merupakan penerus Nabi Muhammad SAW merupakan jaminan yang jauh lebih dipercaya dibandingkan dengan 
seperangkat parameter akuntabilitas yang digagas oleh dunia modern. Komposisi dasar dari komunitas NU yang sebagian besar beraliran Ahlussunah Wal Jamaah. Pendapat Gus Mus tersebut juga sesuai dengan apa yang disebut oleh Sathe (1985) sebagai budaya yang bersifat monolitik dimana Nahdlatul Ulama (NU) melakukan sharing assumption atau berbagi nilai yang sama kepada seluruh anggota organisasinya seperti seragam untuk Banser, atau ada istilah-istilah yang timbul "Wallohul Muwafiq ila aqwamith Thariq, dalam berbagai kegiatan tahlilan, pengajian, serta rasa NU yang sangat kuat.

Semetara itu, bagi warga Nahdliyin yang ingin mendapatkan akses terhadap laporan keuangan NU, menurut Gus Mujib Syadzili bisa dilihat dari setiap akhir pergantian jabatan dalam rapat pleno yang disampaikan pada laporan tahunan. Walaupun laporanya hanya sebatas kas masuk dan keluar, tetapi tetap diterima dengan rasa percaya bahwa semua anggota NU itu menjalankan organisasi dengan ikhlas, lillahita'ala, dan tidak berbuat macam-macam. Hal tersebut sesuai ungkapan Gus Solah:

NU adalah organisasi yang terdiri atas jamaah-jamaah dimana mayoritasnya masih tradisional dalam pola berpikirnya. Pola pemikiran tersebut didasarkan pada upaya yang dilakukan mereka sebagai wujud dari kecintaan mereka terhadap NU. Penyusunan laporan keuangan yang selama ini dilakukan masih terbatas pada kas masuk dan kas keluar. Gus Solah menyatakan bahwa pelaporan kepada publik hampir masih belum ada. Sementara itu, dengan adanya prinsip kejujuran dan keikhlasan inilah yang kemudian menjadikan laporan keuangan kebanyakan minus, tetapi kegiatan tetap berjalan dan selesai. Dengan kata lain, secara sistem keuangan kondisi kas memang minus, namun karena rasa ikhlas inilah maka meskipun tidak dicatat tetapi segala kegiatan selesai dengan baik akibat dari para warga Nahdliyin yang ikhlas dan jujur. Meskipun terkadang para Kiai harus menyerahkan dana pribadinya sebagai tambahan tetapi para donatur yang ikhlas tidak berhenti dan terus menyumbangkan keikhlasannya.

Berdasarkan pendalaman kasus yang dilakukan peneliti, peneliti menemukan bahwa akuntabilitas Lillahita'ala dan Ikhlas ini berbasis pada kehadiran program atau kegitan NU di tengah warga NU. Jika kegitan amaliah seperti pengajian, shalawatan, yasinan, pembagian zakat, infaq, sedekah, dan lain sebagainya hadir di tengah warga NU, maka warga NU dengan sendirinya telah merasakan pertanggungjawaban pengurus NU yang dalam NU dianggap sebagai tindakan Lillahi Ta'ala, tindakan menghidupi organisasi dengan harapan mendapat berkah dari Allah SWT.

Peran Kiai sebagai Inisiator dan Elitist Charismatic Values dalam Membentuk Akuntabilitas Nahdlatul Ulama Berdasarkan Tipe Nilai dalam Organisasi

Peran Kiai sebagai inisiator dalam membentuk Akuntabilitas ditunjukkan adanya pemberian gagasan sesuai dengan kebutuhan warga NU pada khususnya dan Republik Indonesia pada umumnya. Gagasan tersebut berdasarkan hasil analisis sosial dan tafakur kepada Allah SWT. Sebagai inisiator Kiai dapat menggerakan kepentingan-kepentingan dan keterlibatan para pemangku kepentingan dalam organisasi.

Kyai dipandang kharismatik oleh masyarakat yang menjadi variable penentu ketahanan organisasi NU, dalam kedudukan seperti itu Kyai dapat juga disebut agent of change dalam masyarakat yang berperan penting dalam suatu proses perubahan sosial. Berangkat dari teori tersebut dapat disimpulkan bahwa Kyai berperan terhadap Akunatbilitas. Seorang kyai dipandang sebagai sesepuh, figur yang dituakan. Karenanya selain ia berperan sebagai pemberi gagasan dan nasehat dalam berbagai aspek dan persoalan

Berdasarkan temuan dalam penelitian ini, diketahui bahwa NU memiliki cara sendiri dalam proses akuntabilitasnya. Proses akuntabilitas NU ini disebut "Akuntabilitas Khas Lillahita 'ala dan Ikhlas ala Nahdlatul Ulama”. Hal ini sseauai ungkapan Tin Farida Yahya:

Maksud dari akuntabilitas Lillahita'ala dan Ikhlas ini adalah adanya prinsip kejujuran dan keikhlasan dalam menyusun laporan keuangan. Hal ini dikarenakan walaupun secara sistem keuangan kondisi kas memang minus, namun karena rasa ikhlas inilah maka meskipun tidak dicatat, tetapi segala kegiatan selesai dengan baik akibat dari para warga Nahdliyin yang ikhlas dan jujur. Meskipun terkadang para Kiai harus menyerahkan dana pribadinya sebagai tambahan donatur yang dilakukan dengan ikhlas. 
Adanya prinsip kejujuran dan keikhlasan dalam menyusun laporan keuangan atau dengan sebutan Akuntabilitas Khas Lillahita'ala dan Ikhlas ala Nahdlatul Ulama yang dijalankan oleh pengurus NU ini tentu mencerminkan tipe Functional-values, karena nilai-nilai organisasi NU dengan Akuntabilitas Khas Lillahita'ala dan Ikhlas ala Nahdlatul Ulama ini merupakan nilainilai organisasi yang menjadi pedoman bagi anggota dalam menyusun laporan keuangan yang bersifat fungsional dan berasal dari generasi sebelumnya dan terbukti bertahan dari satu generasi ke generasi berikutnya. Pijakan Akuntabilitas Khas Lillahita'ala dan Ikhlas ala Nahdlatul Ulama bertahan dari satu generasi ke generasi berikutnya dan nilai-nilai organisasi tersebut kemudian berubah menjadi tipe nilai functional-traditional values.

Hal ini tentu didasarkan pada representasi dari tipe yang bersifat fungsional dengan memberi kontribusi terhadap efektivitas kinerja laporan keuangan NU dengan nilai-nilai kejujuran dan keikhlasan. Nilai-nilai kejujuran dan keikhlasan dalam menyusun laporan keuangan yang masih sebatas kas keluar dan kas masuk ini kemudian bisa membawa partisipasi yang cukup luas di kalangan anggota organisasi NU itu sendiri, sehingga menjadi susah untuk diadaptasi oleh organisasi lain, mengingat proses terbentuknya yang bersifat gradual (sedikit demi sedikit) dan juga tidak mengikuti konsep pemikiran akuntabilitas modern. Peran Kiai yang memiliki pengaruh besar terhadap santrinya tentu membuat Kiai ini sangat ditaati oleh pengurus organisasi NU. Hal ini dikarenakan pengurus NU adalah seorang santri. Hal tersebut diperkuat dengan pendapat Gus Mus:

Kiai tentu punya pikiran dan kelakuan yang sama dengan Kiai lainnya untuk sedapat mungkin meniru jejaknya Nabi Muhammad SAW. Hal ini lah yang membuat para santri yang duduk sebagai pengurus organisasi NU yakin bahwa Kiai itu penerus Nabi yang harus dipatuhi dan diteladani. Dengan berpedoman pada hal tersebut, maka bagi pengurus NU sudah bisa menjadi jaminan yang jauh lebih dipercaya dibandingkan dengan seperangkat parameter dalam melakukan segala hal, tidak terkecuali dalam menyusun akuntabilitas seperti yang digagas oleh dunia modern.

Peran Kiai yang sedemikian besar tersebut dikategorikan dalam nilai tipe elitist charismatic values, yang merupakan sistem nilai kebanggaan diri dari pimpinan yang kharismatik yang menghasilkan fanatisme para anggota organisasi. Mengingat sifat kharismatik dari kiai bersifat temporer, maka nilai-nilai ini bersifat transisional. Kemudian ketika nilai-nilai dalam organisasi NU yang berasal dari pendiri pesantren itu bisa bertahan sampai sekarang, maka tipe nilai ini berubah menjadi elitist traditional values, sebab nilai yang mendasari operasional yang dilakukan oleh organisasi NU diadopsi dari pesantren dan bersifat elitist yang stabil dan bertahan dari satu generasi ke generasi berikutnya. Dengan begitu menunjukkan nilai-nilai organisasi NU bisa memberi kontribusi keberhasilan organisasi yang mampu bertahan dalam waktu jangka panjang.

Keberhasilan itu juga bisa dilihat dari proses akuntabilitasnya yang masih pada tataran laporan keuangan kas keluar dan kas masuk saja. Akan tetapi, pada kenyataanya organisasi NU masih tetap berkembang dan bahkan menjadi organisasi terbesar di Indonesia sampai saat ini meskipun dalam proses akuntabilitasnya dari tingkat pusat sampai dengan ranting belum ditemukannya pencatatan yang rapi, terstruktur, dan di publish secara continue kepada publik sebagai bentuk tanggung jawab organisasi terhadap publik.

Peran Kiai sebagai elitist charismatic values sesuai dengan pendapat Weiner (1989:534545) ada dua dimensi nilai yaitu fokus dari nilai-nilai tersebut yang dibedakan menjadi dua kategori yaitu apakah nilai-nilai tersebut bersifat fungsional atau elitist. Realita peran Kiai dalam membentuk akuntabilitas NU, menurut Weiner digambarkan sebagai kekawatiran dimana Peran Kiai tidak memberikan kontribusi keberhasilan jangka panjang bagi organisasi karena berasal dari pemimpin organisasi yang sangat bersifat transisional atau juga diartikan sistem nilai kebanggaan diri dari pimpinan yang kharismatik yang menghasilkan fanatisme para anggota organisasi.

\section{SIMPULAN DAN SARAN}

Berdasarkan penelitian tentang peran Kiai dalam membentuk Akuntabilitas NU, diketahui bahwa disamping adanya peran Kiai sebagai Inisiator, NU juga memiliki cara sendiri dalam proses akuntabilitasnya. Proses akuntabilitas NU ini disebut "Akuntabilitas Khas Lillahita'ala dan Ikhlas ala Nahdlatul Ulama". Maksud dari akuntabilitas Lillahita'ala dan Ikhlas ini adalah adanya prinsip kejujuran dan keikhlasan dalam menyusun laporan keuangan.

Adanya peran Kiai yang sedemikian besar tersebut dalam konsep tipe nilai menurut Weiner dikategorikan memiliki nilai tipe elitist charismatic values, yang merupakan sistem nilai kebanggaan diri dari pimpinan yang kharismatik yang menghasilkan fanatisme para anggota or- 
ganisasi. Dikarenakan sifat kharismatik dari Kiai bersifat temporer (sementara), maka nilai-nilai ini bersifat transisional. Mengingat nilai-nilai dalam organisasi NU yang berasal dari pendiri pesantren tersebut mampu berjalan sampai sekarang, maka tipe nilai ini berubah menjadi elitist traditional values, sebab nilai yang mendasari operasional yang dilakukan oleh organisasi NU diadopsi dari pesantren dan bersifat elitist yang stabil dan bertahan dari satu generasi ke generasi berikutnya. Dengan begitu menunjukkan nilai-nilai organisasi NU bisa memberi kontribusi keberhasilan organisasi yang mampu bertahan dalam waktu jangka panjang.

Kemudian berdasarkan temuan dalam penelitian ini, proses akuntabilitas Lillahita'ala dan Ikhlas ala NU yang berprinsip kejujuran dan keikhlasan bisa tetap bertahan dan berjalan dikarenakan walaupun secara sistem keuangan kondisi kas memang minus, namun karena rasa ikhlas inilah maka meskipun tidak dicatat, tetapi segala kegiatan selesai dengan baik akibat dari para warga Nahdliyin yang ikhlas dan jujur.

Adanya prinsip kejujuran dan keikhlasan dalam menyusun laporan keuangan atau dengan sebutan akuntabilitas khas lillahita'ala dan ikhlas ala Nahdlatul Ulama yang dijalankan oleh pengurus NU ini tentu mencerminkan tipe Functional-values, karena nilai-nilai organisasi NU dengan Akuntabilitas khas lillahita'ala dan ikhlas ala Nahdlatul Ulama ini merupakan nilai-nilai organisasi yang menjadi pedoman bagi anggota dalam menyusun laporan keuangan yang bersifat fungsional dan berasal dari generasi sebelumnya dan terbukti bertahan dari satu generasi ke generasi berikutnya.

Bentuk akuntabilitas khas lillahita'ala dan Ikhlas ala Nahdlatul Ulama yang bertahan dari satu generasi ke generasi berikutnya, bahkan sampai sekarang dalam organisasi Nahdlatul Ulama, maka nilai-nilai organisasi tersebut kemudian menjadi tipe nilai functional-traditional values. Hal ini tentu didasarkan pada representasi dari tipe yang bersifat fungsional dengan memberi kontribusi terhadap efektivitas kinerja laporan keuangan NU dengan nilai-nilai kejujuran dan keikhlasan. Nilai-nilai kejujuran dan keikhlasan dalam menyusun laporan keuangan yang masih sebatas kas keluar dan kas masuk ini kemudian bisa membawa partisipasi yang cukup luas di kalangan anggota organisasi NU itu sendiri, sehingga menjadi susah untuk diadaptasi oleh organisasi lain, mengingat proses terbentuknya yang bersifat gradual (sedikit demi sedikit) dan juga tidak mengikuti konsep pemikiran akuntabilitas modern. Meskipun proses akuntabilitas NU masih sederhana, tetapi pada kenyataanya NU masih tetap berkembang dan bahkan menjadi organisasi agama terbesar di Indonesia sampai saat ini.

\section{DAFTAR RUJUKAN}

Awio, G., Northcott, D., \& Lawrence, S. (2011). Social capital and accountability in grass-roots NGOs: The case of the Ugandan community-led HIV/AIDS initiative. Accounting, Auditing and Accountability Journal, 24(1), 63-92. https://doi.org/10.1108/09513571111098063

Baso, A. (2015a). A gama NU untuk NKRI. Tangerang Selatan: Pustaka Afid.

Baso, A. (2015b). Islam Nusantaran ijtihad jenius \& ijma' ulama Indonesia. Tangerang Selatan: Pustaka Afid.

Berry, A. J. (2005). Accountability and control in a cat's cradle. Accounting, Auditing and Accountability Journal, 18(2), 255-297. https://doi.org/10.1108/09513570510588751

Creswell, J. W. (2013). Qualitative Inquiry \& Research Design: Choosing Among Five Approaches. In Sage Publications (2 ed., Vol. 2nd). https://doi.org/10.1111/14679299.00177

Cutt, J., \& Murray, V. (2010). Accountability and Effectiveness Evaluation in Non-Profit Organizations. In Accountability and Effectiveness Evaluation in Non-Profit Organizations (1 ed.). https://doi.org/10.4324/9780203461365

Ebrahim, A. (2003). Accountability In Practice: Mechanisms for NGOs. World Development, 31 (5), 813-829. https://doi.org/10.1016/S0305-750X(03)00014-7

Jacobs, K. (2005). The sacred and the secular: Examining the role of accounting in the religious context. Accounting, Auditing and Accountability Journal, 18(2), 189-210. https:// doi.org/10.1108/09513570510588724

Jayasinghe, K., \& Soobaroyen, T. (2009). Religious "spirit" and peoples' perceptions of accountability in Hindu and Buddhist religious organizations. Accounting, Auditing \& Accountability Journal, 22(7), 997-1028. https://doi.org/10.1108/09513570910987358

Kaplan, R. S. (2001). Strategic performance measurement and management in nonprofit organizations. Nonprofit Management and Leadership, 11(3), 353-370. https:// doi.org/10.1002/nml.11308

Mandasari, M., Darmawan, N. A. S., \& Atmadja, A. T. (2015). Akuntabilitas Pengelolaan 
Keuangan Dana Bansos Pada Majelis Ta'lim Muslimat Nu Ukhuwah Islamiyah Kampung Anyar. JIMA T (Jurnal Ilmiah Mahasiswa A kuntansi S1), 3(1).

Mardiyah, M. (2012). Kepemimpinan Kiai dalam Memelihara Budaya Organisasi di Pondok Modern Gontor, Lirboyo Kediri, dan Pesantren T ebuireng Jombang. Tsaqafah, 8(1), 67. https://doi.org/10.21111/tsaqafah.v8i1.21

Miles, M. B., Huberman, A. M., \& Saldaña, J. (2014). Qualitative data analysis: A methods Sourcebook (3rd Edition). In SAGE Publications, Inc. https:// doi.org/10.1177/239700221402800402

Moleong, L. J. (2012). Metode Penelitian Kualitatif, cet. In Ke-30. Bandung: Remaja Rosdakarya Offset.

Muhammad, F. (2017). Dinamika Pemikiran Dan Gerakan Politik Nahdlatul Ulama. Kalam, 10 (2), 57. https://doi.org/10.24042/klm.v9i1.320

Prugsamatz, R. (2010). Factors that influence organization learning sustainability in non-profit organizations. Learning Organization, 17(3), 243-267. https:// doi.org/10.1108/09696471011034937

Randa, F., Triyuwono, I., Ludigdo, U., \& Sukoharsono, E. G. (2011). Studi Etnografi: Akuntabilitas Spiritual Pada Organisasi Gereja Katolik Yang Terinkulturasi Budaya Lokal. Jurnal Akuntansi Multiparadigma, 2(1), 35-51. Diambil dari http:// jurnal.unmuhjember.ac.id/index.php/sncp/article/view/218

Sathe, V. (1985). Culture and related corporate realities. In Homewood, IL: Irwin. Home Wood: Richard D. Irwin. Inc.

Sutrisno, E. (2010). Budaya organisasi. Jakarta: Kencana Prenada Media Group.

Wiener, Y. (1988). Forms of Value Systems: Focus on Organizational Effectiveness and Cultural Change and Maintenance. Academy of Management Review, 13(4), 534-545. https:// doi.org/10.5465/amr.1988.4307410 